\title{
THE TECHNOLOGY OF WINTER CONCRETING OF MONOLITHIC FRAME STRUCTURES WITH SUBSTANTIATION OF HEAT TREATMENT MODES BY SOLUTIONS OF THE DIFFERENTIAL EQUATION OF THERMAL CONDUCTIVITY OBTAINED BY THE METHOD OF GROUP ANALYSIS
}

\author{
Alexander A. Lazarev \\ Novosibirsk State University of A rchitecture and Civil Engineering (Sibstrin), Novosibirsk, RUSSIA
}

\begin{abstract}
An innovative method for calculating thermal fields inside monolithic structures has been developed, based on the use and analysis of nonlinear differential equations. The innovativeness of the method lies in the approach to the analysis of nonlinear physical processes using nonlinear differential equations. Thanks to the method of group analysis, 13 expressions are obtained from complex mathematical equations, which are easy to use and depend on several empirical coefficients. It is assumed that this calculation method is a priori more accurate than the existing ones, as well as available to people at a construction site without higher mathematical education, which makes it a priority for research. The applicability of this method must be proven by linking empirical coefficients and variables to the conditions of the experiments, while obtaining reliable data that will turn out to be more accurate than the existing calculation methods. This article demonstrates a systematic approach to establishing the suitability of using the method of group analysis of differential equations for problems of winter concreting on the basis of laboratory experiments under stationary conditions. The equations were subject to verification, which, according to the physical description, correspond to the real conditions of the course of thermal processes inside monolithic structures. Based on the obtained processing results, it was decided that it was necessary to further study the innovative method in the conditions of the construction site, but only for some expressions that showed the best results at the stage of laboratory tests.
\end{abstract}

Keywords: W inter concreting, group analysis method, differential equation, experiment, laboratory tests.

\section{ТЕХНОЛОГИЯ ЗИМНЕГО БЕТОНИРОВАНИЯ КАРКАСНЫХ МОНОЛИТНЫХ КОНСТРУКЦИЙ С ОБОСНОВАНИЕМ РЕЖИМОВ ТЕРМООБРАБОТКИ РЕШЕНИЯМИ ДИФФЕРЕНЦИАЛЬНОГО УРАВНЕНИЯ ТЕПЛОПРОВОДНОСТИ, ПОЛУЧЕННЫМИ МЕТОДОМ ГРУППОВОГО АНАЛИЗА}

\author{
A.A. Лазарев \\ Новосибирский Государственный Архитектурно-Строительный Университет (Сибстрин), Новосибирск, \\ РОССИЯ
}

\begin{abstract}
Аннотация. Разработан инновационный метод расчета тепловых полей внутри монолитных конструкций, основанный на использование и анализе нелинейных дифференциальных уравнений. Инновационность метода заключается в подходе к анализу нелинейных физических процессов с помощью нелинейных дифференциальных уравнений. Благодаря методу группового анализа из сложных математических уравнений получены 13 выражений, которые просты в применении и зависят от нескольких эмпирических коэффициентов. Предполагается, что данный метод расчета является априори более точным существующих, а также доступным для людей на строительной площадке без высшего математического образования, что делает его приоритетным для исследования. Применимость данного метода необходимо доказать путем привязки эмпирических коэффициентов и переменных к условиям протекания экспериментов, получая при этом достоверные
\end{abstract}


данные, которые окажутся точнее существующих методов расчета. В данной статье продемонстрирован системный подход к установлению пригодности применения метода группового анализа дифференциальных уравнений для задач зимнего бетонирования на основе лабораторных экспериментов при стационарных условиях. Проверки подлежали уравнения, которые по физическому описанию соответствуют реальным условиям протекания тепловых процессов внутри монолитных конструкций. Исходя из полученных результатов обработки было принято решение о необходимости дальнейшего изучения инновационного способа в условиях строительной площадки, однако только для некоторых выражений, которые показали наилучшие результаты на этапе лабораторных испытаний.

Ключевые слова: Зимнее бетонирование, метод группового анализа, дифференциальное уравнение, эксперимент, лабораторные испытания.

\section{INTRODUCTION}

The issue of strength gain of monolithic structures is fundamental for the construction industry. It has long been established that strength directly depends on the holding temperature of monolithic structures [1]. M any methods have been proposed for calculating thermal fields and strength, but all the proposed methods are either approximate or complex and voluminous for use in a construction site for people without higher mathematical education $[2,3,4]$. A new look at the problem has appeared thanks to the method of group analysis.

The method of group analysis of differential equations, proposed in the middle of the last century $[5,6]$ for solving applied problems using nonlinear differential equations, made it possible to obtain simple and convincing dependences for modeling temperature conditions during heat treatment of concrete hardening in building structures at negative temperatures.

The key parameters of the submodels obtained from the basic nonlinear differential equation of heat conduction are a parameter characterizing the inhomogeneity of the rod and a parameter characterizing the nonlinearity of the process. These parameters depend on many factors. Finding them and matching them for different conditions, for each submodel, will determine its applicability for solving practical problems.
After analyzing the 13 proposed submodels $[7,8], 6$ were selected that are most suitable for assessing the thermal processes occurring in the concrete of an extended structure of the "column" type. These are submodels $\# 1,2,3,7,10,11$. Parameters were determined experimentally for various ambient temperatures and el ectric power during heating.

\section{RESEARCH AND RESULTS}

Based on preliminary experiments $[9,10]$, which demonstrated the prospects of the study, a decision was made on the need for a system of experiments for a more structured analysis. Laboratory tests were carried out in a freezer with a constant temperature, the values of which during one experiment did not deviate from the set temperature by more than $0.2^{\circ} \mathrm{C}$, which confirms the ideal conditions for the experiment.

For the experiment, a column model was prepared, consisting of a formwork structure made of FSF 18 laminated plywood, $18 \mathrm{~mm}$ thick, reinforcing cage, $6 \mathrm{~mm}$ thick rods. As a concrete mixture for the possibility of repeated experiments, a model body was used, the characteristics of which are shown in Table 1. As a heating element, a PNSV $1.8 \mathrm{~mm}$ heating wire (GOST TU 16.K 71-013-88) was used. 
The Technology of Winter Concreting of M onolithic Frame Structures with Substantiation of Heat Treatment M odes by Solutions of the Differential Equation of Thermal Conductivity Obtained by the Method of Group Analysis

Table 1. Materials

\begin{tabular}{|l|l|l|}
\hline \multirow{2}{*}{ M aterials } & \multicolumn{2}{l|}{$\begin{array}{l}\text { Consumption of materials for 1 } \\
\mathbf{m}^{\mathbf{3}}, \mathbf{k g}\end{array}$} \\
\cline { 2 - 3 } & $\begin{array}{l}\text { Standard con- } \\
\text { crete B 22,5 }\end{array}$ & M odel body \\
\hline Diabase crushed stone FR 5-20. GOST 10268-70 & 1250 & 1250 \\
\hline $\begin{array}{l}\text { Quartz sand of the river (Krivodanovsky quarry) M grain= } \\
\text { 1.8. GOST 10268-70 }\end{array}$ & 530 & 530 \\
\hline Portland cement M 400. G OST 10178-68 & 450 & - \\
\hline Crushed sand (Sunit $\left.=2900 \mathrm{~cm}^{2} / \mathrm{g}\right)$ & - & 450 \\
\hline Industrial water GOST 2874-54 & 180 & 180 \\
\hline Bulk weight of concrete / model body, $\mathrm{kg} / \mathrm{m}^{3}$ & 2410 & 2410 \\
\hline
\end{tabular}

In order to establish the regularity of the distribution of the values of the empirical coefficients of the method of group analysis, a series of experiments were carried out under different conditions: at each steady-state temperature: $0^{\circ} \mathrm{C}$, $5^{\circ} \mathrm{C},-10^{\circ} \mathrm{C},-15^{\circ} \mathrm{C}$, experiments were carried out with different heating power: $56 \mathrm{~W}, 108 \mathrm{~W}$, $176 \mathrm{~W}$. The section of the column model and the composition of the model body remained the same.

The heating wire was connected to an electrical network with a voltage of $220 \mathrm{~V}$. The electrical power was changed using a laboratory autotransformer AOSN-20-220-75U HL4 (GOST 15150-69). The power was kept constant throughout the experiment. Power measurements were carried out using periodic monitoring of the current and voltage using a voltammeter. The measurements were made at different loads of the laboratory's electrical network. The limiting power fluctuations did not exceed $2 \mathrm{~W}$, which indicates the reliability of the experiments being carried out.

Experiments, the error of which went beyond the specified limits of the error of power and temperature due to failures, according to the indications of the thermodat and personal control, were excluded from the processing of the results of the experiments.

With a view to generate data for the possibility of further research, 7 chromel-copel thermocouples were installed, located in the center of the structure along its central rod. To process the experiments, we used one thermocouple located in the center of the structure. The rest of the thermocouples were used to assess the likelihood of the main thermocouple, as well as to investigate the second phase - temperature propagation al ong the structure (See Fig. 1).

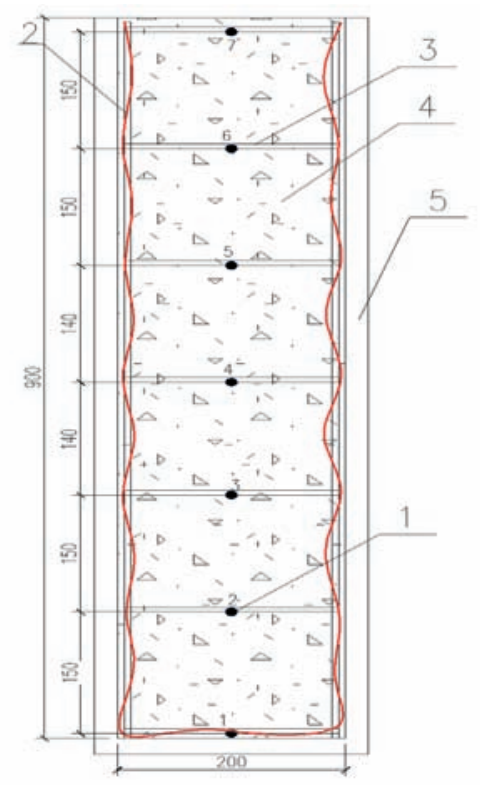

Figure 1. Schematic of the column model. 1 chromel-copel thermocouples, 2 - heating wire, 3 - reinforcing cage, 4 - model body, 5 - model formwork

When processing these experiments, thermocouples located at the centers of the faces of the column model and in the corners (critical points of a monolithic structure during heating) were 
not used to narrow the studied boundaries of applicability of the method of group analysis of differential equations. In the case of a positive verification of the theory in laboratory tests and confirmation by a production experiment, the theory needs to be tested at critical points to create guidelines for the application of the group analysis method.

The results obtained in the laboratory were processed using the M aple software package together with the selection of coefficients, depending on the theoretical equation. The coefficients were selected depending on the best convergence of the theoretical and experimental curves of temperature rise and fall in the column body model.

The results of processing the $T_{1}$ submodel according to the experimental data are shown in Table 2.
The results of processing the $\mathrm{T}_{2}$ submodel according to the experimental data are shown in Table 3.

The results of processing the $T_{3}$ submodel according to the experimental data are shown in Table 4.

The results of processing the $T_{7}$ submodel according to the experimental data are shown in Table 5.

The results of processing the $T_{10}$ submodel according to the experimental data are shown in Table 6.

The results of processing the $T_{11}$ submodel according to the experimental data are shown in Table 7.

Table 2. E mpirical coefficients submodel $\mathrm{T}_{1}$

\begin{tabular}{|c|c|c|c|c|c|c|c|}
\hline \multicolumn{4}{|c|}{ Heating the model } & \multicolumn{4}{|c|}{ Cooling the model } \\
\hline \multirow{2}{*}{ Temperature, ${ }^{\circ} \mathrm{C}$} & \multicolumn{3}{|c|}{ Coefficients } & \multirow{2}{*}{ Temperature, ${ }^{\circ} \mathrm{C}$} & \multicolumn{3}{|c|}{ Coefficients } \\
\hline & $\alpha$ & $\beta$ & $\mathrm{C}_{1}$ & & $\alpha$ & $\beta$ & $\mathrm{C}_{1}$ \\
\hline \multicolumn{8}{|c|}{ Low power case 56W } \\
\hline 0 & 10 & 3,5 & 1,53 & 0 & 1,6 & 3 & 7 \\
\hline-5 & 7,7 & 3,3 & 1,68 & -5 & 1 & 2 & 3 \\
\hline-10 & 3,1 & 3,3 & 1,8 & -10 & - & - & - \\
\hline-15 & - & - & - & -15 & 1 & 1,1 & 4 \\
\hline \multicolumn{8}{|c|}{ M edium power case $108 \mathrm{~W}$} \\
\hline 0 & 9 & 3,24 & 1,37 & 0 & 1,2 & 2,5 & 7 \\
\hline-5 & 6 & 2,9 & 2,15 & -5 & 1 & 2,25 & 7 \\
\hline-10 & 2,4 & 2,37 & 1,36 & -10 & 1 & 2 & 6 \\
\hline-15 & 1,85 & 1,66 & 1,42 & -15 & - & - & - \\
\hline \multicolumn{8}{|c|}{ High Power Case 176W } \\
\hline 0 & 6 & 1,63 & 1,24 & 0 & 0,8 & 2 & 8 \\
\hline-5 & 4,5 & 3,9 & 1,45 & -5 & 0,4 & 2 & 6 \\
\hline-10 & 1,75 & 1,64 & 1,51 & -10 & 0,4 & 2,25 & 16 \\
\hline-15 & 1,8 & 1,95 & 1,58 & -15 & - & - & - \\
\hline
\end{tabular}


The Technology of Winter Concreting of M onolithic Frame Structures with Substantiation of Heat Treatment M odes by Solutions of the Differential Equation of Thermal Conductivity Obtained by the Method of Group Analysis

Table 3. Empirical coefficients submodel $\mathrm{T}_{2}$

\begin{tabular}{|c|c|c|c|c|c|}
\hline \multicolumn{3}{|c|}{ Heating the model } & \multicolumn{3}{|c|}{ Cooling the model } \\
\hline \multirow{2}{*}{ Temperature, ${ }^{\circ} \mathrm{C}$} & \multicolumn{2}{|c|}{ Coefficients } & \multirow{2}{*}{ Temperature, ${ }^{\circ} \mathrm{C}$} & \multicolumn{2}{|c|}{ Coefficients } \\
\hline & $\alpha$ & $\beta$ & & $\alpha$ & $\beta$ \\
\hline \multicolumn{6}{|c|}{ Low power case $56 \mathrm{~W}$} \\
\hline 0 & 1,43 & $-0,475$ & 0 & 14 & 1,5 \\
\hline-5 & 1,13 & $-0,745$ & -5 & 14,5 & 1,5 \\
\hline-10 & 0,83 & $-1,045$ & -10 & - & - \\
\hline-15 & - & - & -15 & 15 & 1,5 \\
\hline \multicolumn{6}{|c|}{ M edium power case $108 \mathrm{~W}$} \\
\hline 0 & 1,03 & $-0,855$ & 0 & 16,5 & 1,5 \\
\hline-5 & 0,5 & $-1,105$ & -5 & 16,45 & 1,5 \\
\hline-10 & 0,41 & $-1,27$ & -10 & 15 & 1,5 \\
\hline-15 & 0,28 & $-1,29$ & -15 & - & - \\
\hline \multicolumn{6}{|c|}{ High Power Case 176W } \\
\hline 0 & 0,5 & $-1,03$ & 0 & 18 & 1,5 \\
\hline-5 & 0,11 & $-1,2$ & -5 & 16,5 & 1,5 \\
\hline-10 & 0,04 & $-1,29$ & -10 & 16,5 & 1,4 \\
\hline-15 & 0,01 & $-1,305$ & -15 & - & - \\
\hline
\end{tabular}

Table 4. Empirical coefficients submodel $T_{3}$

\begin{tabular}{|c|c|c|c|c|c|c|c|}
\hline \multicolumn{4}{|c|}{ Heating the model } & \multicolumn{4}{|c|}{ Cooling the model } \\
\hline \multirow{2}{*}{ Temperature, ${ }^{\circ} \mathrm{C}$} & \multicolumn{3}{|c|}{ Coefficients } & \multirow{2}{*}{ Temperature, ${ }^{\circ} \mathrm{C}$} & \multicolumn{3}{|c|}{ Coefficients } \\
\hline & $\alpha$ & $\beta$ & $\mathrm{C}_{2}$ & & $\alpha$ & $\beta$ & $\mathrm{C}_{2}$ \\
\hline \multicolumn{8}{|c|}{ Low power case 56W } \\
\hline 0 & 6 & 4 & 4,4 & 0 & 3 & 1 & 0,33 \\
\hline-5 & 6 & 4 & 3,5 & -5 & 3 & 1 & 0,39 \\
\hline-10 & 6 & 4 & 2,3 & -10 & - & - & - \\
\hline-15 & - & - & - & -15 & 3 & 1 & 0,153 \\
\hline \multicolumn{8}{|c|}{ M edium power case $108 \mathrm{~W}$} \\
\hline 0 & 6 & 4 & 8,45 & 0 & 3 & 1 & 0,375 \\
\hline-5 & 6 & 4 & 7,85 & -5 & 3 & 1 & 0,4 \\
\hline-10 & 6 & 4 & 5,5 & -10 & 3 & 1 & 0,68 \\
\hline-15 & 6 & 4 & 5,5 & -15 & - & - & - \\
\hline \multicolumn{8}{|c|}{ High Power Case 176W } \\
\hline 0 & 6 & 4 & 12 & 0 & 3 & 1 & 0,41 \\
\hline-5 & 6 & 4 & 15,5 & -5 & 3 & 1 & 0,62 \\
\hline-10 & 6 & 4 & 11 & -10 & 3 & 1 & 0,7 \\
\hline-15 & 6 & 4 & 4,95 & -15 & - & - & - \\
\hline
\end{tabular}


Table 5. Empirical coefficients submodel $\mathrm{T}_{7}$

\begin{tabular}{|c|c|c|c|c|c|c|c|}
\hline \multicolumn{4}{|c|}{ Heating the model } & \multicolumn{4}{|c|}{ Cooling the model } \\
\hline \multirow{2}{*}{ Temperature, ${ }^{\circ} \mathrm{C}$} & \multicolumn{3}{|c|}{ Coefficients } & \multirow{2}{*}{ Temperature, ${ }^{\circ} \mathrm{C}$} & \multicolumn{3}{|c|}{ Coefficients } \\
\hline & $\alpha$ & $\beta$ & $\mathrm{C}_{5}$ & & $\alpha$ & $\beta$ & $\mathrm{C}_{5}$ \\
\hline \multicolumn{8}{|c|}{ Low power case 56W } \\
\hline 0 & 1,4 & 1 & 0,2 & 0 & 1,4 & 1 & 0,63 \\
\hline-5 & 1,4 & 1 & 0,7 & -5 & 1,4 & 1 & 0,645 \\
\hline-10 & 1,4 & 1 & 0,17 & -10 & - & - & - \\
\hline-15 & - & - & - & -15 & 1,4 & 1 & 0,68 \\
\hline \multicolumn{8}{|c|}{ M edium power case $108 \mathrm{~W}$} \\
\hline 0 & 1,4 & 1 & 0,64 & 0 & 1,4 & 1 & 0,86 \\
\hline-5 & 1,4 & 1 & 0,5 & -5 & 1,4 & 1 & 0,93 \\
\hline-10 & 1,4 & 1 & 0,52 & -10 & 1,4 & 1 & 1,33 \\
\hline-15 & 1,4 & 1 & 0,65 & -15 & - & - & - \\
\hline \multicolumn{8}{|c|}{ High Power Case 176W } \\
\hline 0 & 1,4 & 1 & 0,8 & 0 & 1,4 & 1 & 1,34 \\
\hline-5 & 1,4 & 1 & 1,15 & -5 & 1,4 & 1 & 2,29 \\
\hline-10 & 1,4 & 1 & 0,85 & -10 & 1,4 & 1 & 1,265 \\
\hline-15 & 1,4 & 1 & 5 & -15 & - & - & - \\
\hline
\end{tabular}

Table 6. Empirical coefficients submodel $T_{10}$

\begin{tabular}{|c|c|c|c|c|c|c|c|}
\hline \multicolumn{4}{|c|}{ Heating the model } & \multicolumn{4}{|c|}{ Cooling the model } \\
\hline \multirow{2}{*}{ Temperature, ${ }^{\circ} \mathrm{C}$} & \multicolumn{3}{|c|}{ Coefficients } & \multirow{2}{*}{ Temperature, ${ }^{\circ} \mathrm{C}$} & \multicolumn{3}{|c|}{ Coefficients } \\
\hline & $\beta$ & $\mathrm{C}_{8}$ & $\mathrm{C}_{9}$ & & $\beta$ & $\mathrm{C}_{8}$ & $\mathrm{C}_{9}$ \\
\hline \multicolumn{8}{|c|}{ Low power case 56W } \\
\hline 0 & 1,65 & 5 & 6 & 0 & 1,5 & 3 & 2 \\
\hline-5 & 2 & 3 & 4 & -5 & 1,3 & 3 & 2 \\
\hline-10 & 2 & 1 & 2 & -10 & - & - & - \\
\hline-15 & - & - & - & -15 & 1,25 & -1 & 1 \\
\hline \multicolumn{8}{|c|}{ M edium power case $108 \mathrm{~W}$} \\
\hline 0 & 1,45 & 6 & 7 & 0 & 1,3 & 4 & 3 \\
\hline-5 & 1,5 & 4 & 5 & -5 & 1,25 & 4 & 3 \\
\hline-10 & 1,55 & 2 & 3 & -10 & 1,15 & 5 & 4 \\
\hline-15 & 1,6 & 12 & 12 & -15 & - & - & - \\
\hline \multicolumn{8}{|c|}{ High Power Case 176W } \\
\hline 0 & 1,4 & 7 & 8 & 0 & 1,25 & 4 & 3 \\
\hline-5 & 1,25 & 5 & 6 & -5 & 1,05 & 5 & 4 \\
\hline-10 & 1,3 & 3 & 4 & -10 & 1,1 & 5 & 4 \\
\hline-15 & 0,8 & 13 & 14 & -15 & - & - & - \\
\hline
\end{tabular}


The Technology of Winter Concreting of M onolithic Frame Structures with Substantiation of Heat Treatment M odes by Solutions of the Differential Equation of Thermal Conductivity Obtained by the Method of Group Analysis

Table 7. E mpirical coefficients submodel $\mathrm{T}_{11}$

\begin{tabular}{|c|c|c|c|c|c|c|c|}
\hline \multicolumn{4}{|c|}{ Heating the model } & \multicolumn{4}{|c|}{ Cooling the model } \\
\hline \multirow{2}{*}{ Temperature, ${ }^{\circ} \mathrm{C}$} & \multicolumn{3}{|c|}{ Coefficients } & \multirow{2}{*}{ Temperature, ${ }^{\circ} \mathrm{C}$} & \multicolumn{3}{|c|}{ Coefficients } \\
\hline & $\beta$ & $\mathrm{C}_{10}$ & $\mathrm{C}_{11}$ & & $\beta$ & $\mathrm{C}_{10}$ & $\mathrm{C}_{11}$ \\
\hline \multicolumn{8}{|c|}{ Low power case $56 \mathrm{~W}$} \\
\hline 0 & 1,6 & 2 & 5 & 0 & 1,5 & 5 & 8 \\
\hline-5 & 1,8 & 2 & 5 & -5 & 1,3 & 6 & 9 \\
\hline-10 & 2,1 & 2 & 5 & -10 & - & - & - \\
\hline-15 & - & - & - & -15 & 1,2 & 2 & 2 \\
\hline \multicolumn{8}{|c|}{ M edium power case $108 \mathrm{~W}$} \\
\hline 0 & 1,32 & 2 & 5 & 0 & 1,3 & 5 & 9 \\
\hline-5 & 1,36 & 2 & 5 & -5 & 1,2 & 6 & 9 \\
\hline-10 & 1,515 & 2 & 5 & -10 & 1,1 & 6 & 11 \\
\hline-15 & 1,54 & 2 & 5 & -15 & - & - & - \\
\hline \multicolumn{8}{|c|}{ High Power Case 176W } \\
\hline 0 & 1,16 & 2 & 5 & 0 & 1,2 & 5 & 7 \\
\hline-5 & 1,18 & 2 & 5 & -5 & 1,05 & 7 & 13 \\
\hline-10 & 1,245 & 2 & 5 & -10 & 1 & 8 & 9 \\
\hline-15 & 1,265 & 2 & 5 & -15 & - & - & - \\
\hline
\end{tabular}

\section{CONCLUSION}

Drawing a conclusion based on the processing of experimental data according to the criteria: the percentage of discrepancy, the approximate dependence in the values of the coefficients, we can say that only three of the submodels presented have demonstrated a satisfactory result and are recommended for experimental verification by a series of experiments on the construction site in real conditions:

$$
\begin{gathered}
\mathrm{T}_{1}=\mathrm{c}_{1} \mathrm{x}^{\frac{1-\alpha}{\beta+1}}\left(\varepsilon^{\prime}(\mathrm{t})\right)^{\frac{1}{\beta}} \\
\mathrm{T}_{3}=c_{2} x^{-1}\left(\varepsilon^{\prime}(t)\right)^{\frac{1}{\beta}} \\
\mathrm{T}_{11}=\left(\varepsilon^{\prime}(\mathrm{t})\right)^{\frac{1}{\beta}}\left(\mathrm{c}_{0} \ln \mathrm{x}+\mathrm{c}_{11}\right)^{\frac{1}{\beta+1}}
\end{gathered}
$$

This clearly demonstrates their applicability for modeling thermal processes, and hence the acquisition of strength by concrete in structures of the "column" type.
It should be noted that all presented sub-models have several dependences depending on the initial parameters of experiments, such as power and ambient temperature. With a view to streamline the results and precisely identify patterns, it is necessary to conduct a series of reinforcing experiments at the construction site to establish the relationship between heat treatment conditions and empirical coefficients.

\section{REFERENCES}

1. Guidelines for the production of concrete work in winter conditions in the regions of the Far East, Siberia and the Far North / TSNIIOM TP Gosstroy of the USSR - M .: Stroyizdat, 1982 213 p.Author, F., Author, S.: Title of a proceedings paper. In: Editor, F., Editor, S. (eds.) CONFERENCE 2016, LNCS, vol. 9999, pp. 1-13. Springer, Heidel berg (2016).

2. Skramtaev B.G. A bout the formula for determining the strength of concrete. Construction industry, 1932, N o. 1. 
3. Kondratyev G.M. R egular thermal regime. M. : GITTL. 1954. - 408 p.

4. Lykov A.V. Theory of heat conduction. M. : Higher school. 1967-599 3.

5. L.V. Ovsyannikov. Group analysis of differential equations. // M: Nauka, 1978. 398 p..

6. Chirkunov Yu.A., Khabirov S.V. Elements of symmetry analysis of differential equations of continuum mechanics. Novosibirsk. NSTU. 2012.659 p.

7. Chirkunov Yu.A. Nonlinear heat propagation in a non-uniform rod under the influence of a non-stationary heat source as applied to the problems of winter concreting. // Izv. universities. Building. 2018. N o. 2., 70-76 p.

8. V.V. Molodin, Yu.A. Chirkunov, S.N. Shpanko, E.V. Garms, K.E. Gorshkova, D.S. Kasyanov, A.A. Lazarev, S.E. Sarafyan. Nonlinear submodels describing heat propagation during winter concreting of a column in the presence of an external non-stationary heat source. // Izv. universities. B uilding. 2019. N o. 12. - p. 75-86.

9. V.V. Molodin. Nonlinear modeling of heat distribution during winter concreting of a column / V.V. M olodin, Y u.A. Chirkunov., N.F. B elmetsev, E.V. Garms, K.E. Gorshkova. A.A. Lazarev // Izvestiya VUZov. Construction. 2020, N 0. 5, 118-131 p.

10. V. Molodin, Y. Chirkunov, S. Shpanko, E. Garms, K. Gorshkova, A. Lazarev. $M$ athematical modelling of winter concreting//IOP Publishing - 2020, doi:10.1088/1757-899X/953/1/012027

\section{СПИСОК ЛИТЕРАТУРЫ}

1. Руководство по производству бетонных работ в зимних условиях в районах Дальнего Востока, Сибири и Крайнего
Севера / ЦНИИОМТП Госстроя СССР. М. : Стройиздат, 1982 - 213 с.

2. Скрамтаев Б.Г. О формуле для определения прочности бетона. Строительная промышленность, 1932, №1

3. Кондратьев Г.М. Регулярный тепловой режим. М.: ГИТТЛ. 1954. - 408c.

4. Лыков А.В. Теория теплопроводности. М.: Высшая школа. 1967- 599 с.

5. Л.В. Овсянников. Групповой анализ дифференциальных уравнений. //M. : Наука, 1978. - 398 с.

6. Чиркунов Ю.А., Хабиров С.В. Элементы симметрийного анализа дифференциальных уравнений механики сплошной среды. Новосибирск. НГТУ. 2012. 659 с.

7. Чиркунов Ю.А. Нелинейное распространение тепла в неоднородном стержне при воздействии нестационарного источника тепла применительно к задачам зимнего бетонирования. // Изв. вузов. Стр-во. 2018. № 2. - С. 70-76.

8. В.В. Молодин, Ю.А. Чиркунов, С.Н. Шпанко, Е.В. Гармс, К.Е. Горшкова, Д.С. Касьянова, А.А. Лазарев, С.Е. Сарафян. Нелинейные подмодели, описывающие распространение тепла при зимнем бетонировании колонны при наличии внешнего нестационарного источника тепла. // Изв. вузов. Стр-во. 2019. №12. - С. 75-86

9. Молодин В.В. Нелинейное моделирование распределения тепла при зимнем бетонировании колонны / В.В. Молодин, Ю.А Чиркунов., Н.Ф. Бельмецев, Е.В. Гармс, К.Е. Горшкова. А.А. Лазарев // Известия ВУЗов. Строительство.2020, №5 с. 118-131

10. V. Molodin, Y. Chirkunov, S. Shpanko, E. Garms, K. Gorshkova, A. Lazarev. $M$ athematical modelling of winter concreting//lOP Publishing - 2020, doi:10.1088/1757-899X/953/1/012027
Alexander $A$. Lazarev, M aster's student of the Novosibirsk State University of A rchitecture and Civil Engineering (Sibstrin). E-mail: laz.alexx98@yandex.ru.
Лазарев Александр Андреевич, магистрант Новосибирского Государственного АрхитектурноСтроительного Университета (Сибстрин). Эл. почта: laz.alexx98@yandex.ru. 